\title{
Correction to: Population pharmacokinetic approach for evaluation of treosulfan and its active monoepoxide disposition in plasma and brain on the basis of a rat model
}

\author{
Dorota Danielak $^{1}$ (D) Michał Romański ${ }^{1} \cdot$ Anna Kasprzyk $^{1} \cdot$ Artur Teżyk $^{2}$ • Franciszek Główka ${ }^{1}$
}

Published online: 12 August 2020

(c) The Author(s) 2020

\section{Correction to: Pharmacological Reports https://doi.org/10.1007/s43440-020-00115-0}

The original version of this article, published on 30 May 2020 contained a mistake.

The authors regret that some of the constants mentioned throughout the article were expressed in an incorrect unit, which is "L/h" instead of " $1 / \mathrm{h}$ ". These include all of the first-order constants: $\mathrm{k}_{12}, \mathrm{k}_{23}, \mathrm{k}_{45}$, elimination constants of treosulfan and EBDM from plasma and the brain, transformation rate constant of treosulfan to EBDM, transformation rate constant of EBDM to DEB, and hydrolysis constant of EBDM

The original article has been corrected.

The original article can be found online at https://doi.org/10.1007/ s43440-020-00115-0.

Dorota Danielak

danielak@ump.edu.pl

Michał Romański

michalroman@ump.edu.pl

Anna Kasprzyk

annakasprzyk87@gmail.com

Artur Teżyk

atezyk@ump.edu.pl

Franciszek Główka

glowka@ump.edu.pl

1 Department of Physical Pharmacy and Pharmacokinetics, Poznan University of Medical Sciences, Święcickiego 6 St, 60-781 Poznań, Poland

2 Department of Forensic Medicine, Poznan University of Medical Sciences, Święcickiego 6 Street, 60-781 Poznań, Poland
Open Access This article is licensed under a Creative Commons Attribution 4.0 International License, which permits use, sharing, adaptation, distribution and reproduction in any medium or format, as long as you give appropriate credit to the original author(s) and the source, provide a link to the Creative Commons licence, and indicate if changes were made. The images or other third party material in this article are included in the article's Creative Commons licence, unless indicated otherwise in a credit line to the material. If material is not included in the article's Creative Commons licence and your intended use is not permitted by statutory regulation or exceeds the permitted use, you will need to obtain permission directly from the copyright holder. To view a copy of this licence, visit http://creativecommons.org/licenses/by/4.0/.

Publisher's Note Springer Nature remains neutral with regard to jurisdictional claims in published maps and institutional affiliations. 